\title{
COMMUNICATING ACROSS CULTURES
}




\section{COMMUNICATING \\ ACROSS CULTURES}

MAUREEN GUIRDHAM

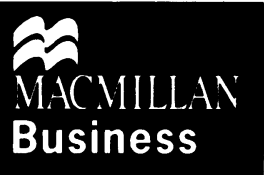


(c) Maureen Guirdham 1999

All rights reserved. No reproduction, copy or transmission of this publication may be made without written permission.

No paragraph of this publication may be reproduced, copied or transmitted save with written permission or in accordance with the provisions of the Copyright, Designs and Patents Act 1988, or under the terms of any licence permitting limited copying issued by the Copyright Licensing Agency, 90 Tottenham Court Road, London W1P OLP.

Any person who does any unauthorised act in relation to this publication may be liable to criminal prosecution and civil claims for damages.

The author has asserted her right to be identified as the author of this work in accordance with the Copyright, Designs and Patents Act 1988.

First published 1999 by

MACMILLAN PRESS LTD

Houndmills, Basingstoke, Hampshire RG21 6XS

and London

Companies and representatives

throughout the world

ISBN 978-0-333-75410-8 ISBN 978-1-349-27462-8 (eBook)

DOI $10.1007 / 978-1-349-27462-8$

A catalogue record for this book is available from the British Library.

This book is printed on paper suitable for recycling and made from fully managed and sustained forest sources.

$\begin{array}{cccccccccc}10 & 9 & 8 & 7 & 6 & 5 & 4 & 3 & 2 & 1 \\ 08 & 07 & 06 & 05 & 04 & 03 & 02 & 01 & 00 & 99\end{array}$

Editing and origination by

Aardvark Editorial, Mendham, Suffolk 
About this book

2.1 Nationality and ethnicity 12

$\begin{array}{lll}2.2 & \text { Gender } & 16\end{array}$

2.3 People with disabilities 20

$\begin{array}{ll}2.4 & \text { Other societal groups } \\ 2.5\end{array}$

2.5 Discrimination 24

2.6 Harassment 33

2.7 Organisational policies and cultures 35

2.8 Explanations of the differences in employment realities and $\begin{array}{ll}\text { opportunities for different groups } & 43\end{array}$

2.9 Conclusion $\quad 44$

References $\quad 44$

$\begin{array}{lll}\text { CHAPTER } 3 & \text { HOW CULTURES DIFFER } & \mathbf{4 7}\end{array}$

$\begin{array}{lll}3.1 & \text { Explanations of cultural difference } & 47\end{array}$

3.2 Communication as the basis of cultural difference 59

$\begin{array}{lll}3.3 & \text { Cultural differences at work } & 64\end{array}$

$\begin{array}{lll}3.4 & \text { Cultural change and generalisability } & 69\end{array}$

$\begin{array}{lll}3.5 & \text { Conclusion } & 76\end{array}$

$\begin{array}{ll}\text { References } & 77\end{array}$

4.1 Universals versus cultural specifics in communication $\quad 79$

4.2 Basic communication elements $\quad 80$

$\begin{array}{lll}4.3 & \text { Language use } & 106\end{array}$ 
4.4 Conclusion

References

CHAPTER 5 (SUB)CULTURAL COMMUNICATION AT WORK - 2

5.1 Antecedents of communication behaviour 117

$\begin{array}{lll}5.2 & \text { Interaction theories } & 134\end{array}$

$\begin{array}{lll}5.3 & \text { Face negotiation } & 139\end{array}$

$\begin{array}{ll}5.4 \text { Conclusion } & 154\end{array}$

$\begin{array}{ll}\text { References } & 155\end{array}$

CHAPTER 6 BARRIERS TO COMMUNICATING ACROSS CULTURES

6.1 The general problem of intergroup communication 160

$\begin{array}{lll}6.2 & \text { Stereotyping } & 161\end{array}$

$\begin{array}{lll}6.3 & \text { Prejudice } & 166\end{array}$

6.4 Cultural differences in communication as barriers 169

6.5 Behavioural barriers to intercultural communication $\quad 174$

6.6 Other barriers to cross-cultural communication at work 182

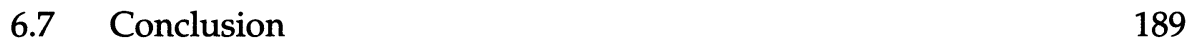

$\begin{array}{ll}\text { References } & 189\end{array}$

\begin{tabular}{l|l} 
CHAPTER 7 & 192
\end{tabular}

$\begin{array}{lll}7.1 & \text { Definitions and concepts } & 193\end{array}$

$\begin{array}{ll}7.2 & \text { States, traits, styles and situations } \\ 7.3 & \text { Comm }\end{array}$

$\begin{array}{lll}7.3 & \text { Communication resourcefulness } & 198\end{array}$

$\begin{array}{lll}7.4 & \text { Episode representation theory } & 199\end{array}$

7.5 A constructivist approach to intercultural communication 201

$\begin{array}{lll}7.6 & \text { Expectations theories } & 203\end{array}$

7.7 Anxiety/uncertainty management theory (AUM) 206

$\begin{array}{lll}7.8 & \text { Cultural identity negotiation theory } & 212\end{array}$

7.9 Communication accommodation theory (CAT) 214

$\begin{array}{ll}7.10 & \text { Ellingsworth's adaptation theory }\end{array}$

$\begin{array}{lll}7.11 & \text { Network theory } & 222\end{array}$

$\begin{array}{lll}7.12 & \text { Intercultural communication effectiveness } & 226\end{array}$

$\begin{array}{ll}7.13 \text { Conclusion } & 230\end{array}$

$\begin{array}{ll}\text { References } & 233\end{array}$

\begin{tabular}{l|l|l|l|l} 
CHAPTER 8 & SKILLS FOR WORKING WITH DIVERSITY
\end{tabular}

$\begin{array}{lll}8.1 & \text { Inclusive language } & 237\end{array}$

8.2 Good intercultural communication behaviours 240

8.3 Applying theory to improve intercultural communication 259

$\begin{array}{lll}8.4 & \text { Conclusion } & 267\end{array}$

$\begin{array}{ll}\text { References } & 268\end{array}$ 
CONTENTS

$\begin{array}{lll}9.1 & \text { Cultural orientation skills } & 271\end{array}$

$\begin{array}{lll}9.2 & \text { Sojourning } & 280\end{array}$

$\begin{array}{lll}9.3 & \text { Conclusion } & 298\end{array}$

$\begin{array}{lr}\text { References } & 298\end{array}$

\section{APPENDIX: EXTRACTS FROM USA STATE DEPARTMENT'S}

HUMAN RIGHTS REPORTS 1996

France

Germany

Italy

303

United Kingdom

305

FURTHER READING 


\section{LIST OF TABLES AND FIGURES}

\section{TABLES}

2.1 Ethnic group percentages in Great Britain $1991 \quad 15$

2.2 United Kingdom employment data for men and women 1994 and 1997

2.3 Percentage of women's share in the main professional categories, Eastern and Western Europe 1990

3.1 Effects of cultural values on work norms

3.2 Effects of culture on groupwork

4.1 Relations among different cultural values and communication styles

5.1 Gender differences in the emotional responsiveness of managers

5.2 A summary of low-context and high-context face negotiation processes

5.3 A typology of face-threatening acts (FTAs)

9.1 Three different approaches to sojourner preparation

\section{FIGURES}

2.1 People with disabilities looking for a job as a percentage of all unemployed

3.1 Power distance and individualism/collectivism interactions for eight countries

3.2 An example of cultural identities at work according to cultural identity theory

4.1 Managers' communication choices based on a purpose continuum 
4.2 Relevance theory account of how message receivers infer speakers' intentions

5.1 Relation between the content of Chapters 4 and 5

5.2 Behavioural constructs and communication behaviours

5.3 Brewer's optimal distinctiveness theory

5.4 Face maintenance in Japan

5.5 Conversational constraints, interaction goals and choice of conversational strategy

6.1 How stereotypes distort communication

6.2 Sources of communication problems and conflict in diverse work groups

7.1 How people define an encounter as intergroup

7.2 Salience of different encounters

7.3 Expectations states theory: factors influencing expectations

7.4 The elements of anxiety/uncertainty management theory

7.5 Key tenets of intercultural identity negotiation theory

7.6 An example of the basic processes of communication acommodation theory

7.7 Intercultural encounters in communication accommodation theory

$\begin{array}{lll}7.8 & \text { Initial orientations of subordinate group members } & 217\end{array}$

$\begin{array}{lll}7.9 & \text { Intercultural communication competence measures } & 229\end{array}$

7.10 A summary of intercultural communication theory elements

8.1 The cognitive resourcefulness continuum

8.2 Ease and difficulty of perceiving factors influencing others' behaviour at work

9.1 Kolb's model for learning from experience 279

$\begin{array}{lll}9.2 & \text { Learned helplessness and culture shock } & 287\end{array}$

9.3 Ady's domain model of sojourner adjustment 289

9.4 Sojourner adjustment over time: U-shaped curve hypothesis 290

9.5 Factors affecting differences in individuals' rates of intercultural adaptation

9.6 Effects of sojourner's ethnic identity strength on intercultural adaptation 


\section{PREFACE}

The impetus behind the writing and publication of this book has been a utilitarian one: there is a widespread and urgent need to improve the ability of people at work to understand and be understood by others whose different backgrounds mean that they communicate differently. Ironically, this need is greatest where it is least recognised, among the members of the dominant groups in society. The members of the 'minority' groups have accommodated so well and the cultural sensitivity of the dominant groups has been so poor that the latter do not, in the main, realise that ways of communicating other than their own exist, persist and have validity; nor that, by imposing their own way, they limit their ability to understand those with whom they work and lose the potential benefits of diversity. In the UK, acknowledgement of the issue is largely confined to a weak complaint that 'We are not very good at learning languages'. Only in the field of international business is there any real sense that something is amiss.

Therefore, my purpose in this book is a focused one: to help the need for intercultural communication skills at work to become better recognised and to contribute my understanding of the knowledge and skill areas required. For this reason, the aspects of subjects such as culture and communication which are covered are those I deem central to this purpose. I realise that others may disagree with my selection and/or the fact that I have not attempted complete coverage of subjects which are foundation disciplines for my study nor argued my epistemological and ontological positions nor entered the postmodernism debate. I hope that readers will nevertheless find the book useful.

The book is dedicated to my children, Damon and Oliver. 


\section{ACKNOWLEDGEMENTS}

My thanks are due to several people who have been kind enough to read and comment on draft chapters of this book - especially to Alan Bennett and E.D. Berman, MBE; to my many friends and colleagues in Bulgaria, the Czech Republic, Hungary, Kazakhstan, Poland, South Africa, the UK, the USA and Uzbekistan, from whom I have learnt by experience and through shared discussion; and to individuals and organisations who generously gave of their time and ideas for the interviews which formed an important part of my research. Every effort has been made to contact all copyright holders but if any have been inadvertently omitted the publishers will be pleased to make the necessary arrangement at the earliest opportunity. 